\title{
Co-Amorphization of Ibuprofen by Paracetamol for Improved Processability, Solubility, and In vitro Dissolution
}

\author{
Mayuri S. Bhandari, ${ }^{1}$ Sarika M. Wairkar, ${ }^{2}$ Udaykumar S. Patil ${ }^{1}$ \\ and Namdeo R. Jadhav ${ }^{1, *}$ \\ ${ }^{1}$ Department of Pharmaceutics, Bharati Vidyapeeth College of Pharmacy, Kolhapur Maharashtra-416013, India. \\ ${ }^{2}$ Shobhaben Pratapbhai Patel School of Pharmacy \& Technology Management, SVKMs NMIMS, Vile Parle (W), Mumbai. \\ Maharashtra - 400 056, India. \\ * Corresponding author: E-mail: nrjadhav18@rediffmail.com \\ Tel: +91-9823751579; Fax: +91-231-2638833
}

Received: 03-09-2017

\begin{abstract}
Co-amorphous (COAM) systems of ibuprofen (IB) and paracetamol (PA), in clinical dose ratios, were prepared by ball milling to enhance solubility and dissolution of IB. Subsequently, COAM were characterized by solubility, processability, XRPD, DSC, ATR-FTIR, SEM, in-vitro dissolution and accelerated stability studies. Maximum increase in aqueous solubility of IB was seen in 500:200 mg dose ratio (COAM 1) with 6.7 fold rise from $78.3 \pm 1.1$ to $522.6 \pm 1.29 \mu \mathrm{g} / \mathrm{ml}$. COAM 1 exhibited $99.80 \pm 0.58 \%$ dissolution of IB at $20 \mathrm{~min}$ in phosphate buffer, significantly high $(\mathrm{P}<0.05)$ compared to plain IB. Thus saturation solubility and dissolution rate of IB was found significantly improved unlike PA. The flowability/processability of COAM system was remarkably improved compared to pure IB, speculated due to as formation of miniscular forms of PA-IB, having strong adhesive interactions. XRPD and DSC results confirmed amorphization of IB. ATR-FTIR results evidenced hydrogen bonding interactions between both the drugs. In accelerated stability studies, flowability, XRPD, DSC and in-vitro dissolution studies demonstrated insignificant changes, thus confirming successful stabilisation of IB by PA.
\end{abstract}

Keywords: Ibuprofen; co-amorphism with paracetamol; improved processability; solubility and dissolution of ibuprofen

\section{Introduction}

Ibuprofen (2-(4-(2-methylpropyl) phenyl) propionic acid) is a widely used non-steroidal anti-inflammatory drug having poor solubility and high permeability (BCS II), and limited bioavailability. ${ }^{1}$ However, it has a poor processability due to its low glass transition temperature ( $\mathrm{Tg}$ ), thus, enunciating difficulty in the design of solid dosage forms. ${ }^{2}$

So as to overcome its aforesaid problems, solid dispersions (SDs) using polyethylene glycol, polyvinyl pyrrolidone, microcrystalline cellulose, colloidal silicon dioxide, HPMC, soluplus, employing techniques like spray drying, freeze drying, electro-spinning, hot melt extrusion, ball milling etc. have been attempted. ${ }^{3-9}$ These SDs demonstrated solubility and dissolution enhancement by amorphization, solid solution formation, non-covalent interactions like hydrogen bonding etc. However, ibuprofen due to its low melting temperature devitrifies rapidly and post process residual crystallites act as nuclei for further crystallisation. Additionally, a large quantity of polymer increases the bulk of the final dosage form. ${ }^{10}$ Hence, commercial applications of SDs have been limited due to their stability, reproducibility, and scale up constraints. ${ }^{11,12} \mathrm{Un}$ like SDs, micronization of Ibuprofen has been found to be of limited significance due to a slight reduction in its crystallinity. When processed alone, its in-situ homodimer formation impedes crystallinity reduction and vitrification, and consequently results into poor solubilisation. ${ }^{13}$ Relatively, crystal habit change and co-crystallisation have been found to be promising crystal engineering techniques aiming aforesaid improvements. ${ }^{14}$ Use of ionic liquids and self assembled mixed micelles of surfactant have also been reported for solubility enhancement of ibuprofen. ${ }^{15-16}$ But, safety and toxicity of solvent, surfactant, and co-crystal 
former are prime concerns. Recently, a new technique using mesoporous silica has been introduced to overcome the solubility and stability problems of ibuprofen. ${ }^{17}$ Use of mesoporous SBA-15, modified SBA-16, and MCM-41 has been attempted to stabilise amorphous state and enhance its dissolution. However, it possesses high manufacturing costs due to expensive silica sources and surfactants used in the fabrication. ${ }^{18}$ To alleviate cost, its stabilization has also been attempted using inexpensive mesoporous magnesium carbonate. ${ }^{19}$ Recently, co-processing of Ibuprofen-magnesium trisilicate has been carried out by ball milling and freeze drying for imparting amorphism and improved drug release of former. ${ }^{20}$

Two decades ago, the concept of co-amorphism was introduced, demonstrating potential binary amorphous system, comprising two or more small molecules instead of polymers. ${ }^{21-22}$ Studies have shown that small molecules like amino acids, sugar, urea, citric acid, kaolin, aluminium hydroxide ${ }^{23}$ or other API can improve physical stability of the amorphous drugs more effectively than polymers. ${ }^{24-26}$ The main reason for the stability of the co-amorphous system was attributed to molecular interactions between the drugs/excipient in the system. It was reported that unstable drug like Naproxen could be stabilized by Indomethacin and Cimetidine, and dissolution rates of these systems were also enhanced. ${ }^{27}$ Löbmann et al. have reported improvement in both stability and solubility of Glipizide when combined with Simvastatin. ${ }^{28}$ Further, ball milled Nateglinide-Metformin hydrochloride co-amorphous system has demonstrated improved dissolution of Nateglinide. ${ }^{29}$ Interestingly, carbamazepine, citric acid and L-arginine ternary system was ball milled for inducing coamorphism, to enhance $\mathrm{Tg}$ and solubility/dissolution. ${ }^{30}$

Keeping in view benefits reaped from appropriate co-amorphous combinations of two drugs, we have attempted to improve processability, solubility and in vitro dissolution, and amorphous state stability of Ibuprofen using Paracetamol, which is a BCS class III drug. Clinically relevant combinations of both drugs are available in the market and have been widely recommended for analgesic, antipyretic, and anti-inflammatory conditions. Predominantly available three clinical dose combinations viz; 500 mg: $200 \mathrm{mg}, 500 \mathrm{mg}$ : $400 \mathrm{mg}$ and $325 \mathrm{mg}$ : $400 \mathrm{mg}$ of Paracetamol: Ibuprofen were ball milled for coamorphism. The simplicity, versatility and green nature of ball milling technique has compelled us to employ same. Eventually, prepared coamorphous mixtures (COAM) were characterized by solubility, micromeritic properties, flowability, ATR-FTIR, DSC, XRPD and In-vitro dissolution studies.

\section{Experimental}

\section{1. Materials}

Ibuprofen and Paracetamol were provided as a gift samples by Wintech Pharmaceuticals, Nashik, India and
Sanofi India Ltd., Mumbai, India respectively. All other reagents used in the study were of analytical grade.

\section{2. Methods}

\section{2. 1. Preparation of COAM and Saturation Solubility Studies}

Paracetamol (PA) and Ibuprofen (IB) were ball milled (Lab Hosp, Mumbai, India) together in clinically available dose ratios $500 \mathrm{mg}: 200 \mathrm{mg}$ (COAM 1), $500 \mathrm{mg}$ : $400 \mathrm{mg}$ (COAM 2) and $325 \mathrm{mg}: 400 \mathrm{mg}$ (COAM 3) of PA: IB respectively. The COAM of PA and IB were ball milled using $8 \mathrm{~mm}$ stainless steel balls at critical speed of $120 \mathrm{rpm}$ for $2 \mathrm{~h}$. The milling speed and time was optimised after taking trials, based on increase in solubility of COAM. Also, both pure drugs were ball milled separately, PA (BMP) and IB (BMI) at same milling parameters. Physical mixtures (PM) of pure PA and IB were prepared, and all aforementioned samples were stored in desiccators until further use.

Subsequently, saturation solubility of PA and IB was determined by adding excess amount of each drug in 10 $\mathrm{mL}$ distilled water separately. The dispersions were kept on an orbital shaker (Remi Instruments Ltd., Mumbai, India) for $72 \mathrm{~h}$ at $37^{\circ} \mathrm{C}$ and further centrifuged at $7000 \mathrm{rpm}$ for $10 \mathrm{~min}$. The supernatant was filtered through $0.45 \mu \mathrm{m}$ syringe filter and the concentration of each drug was determined by simultaneous UV-spectrophotometric analysis (Jasco V 530, India) at absorption maxima $243 \mathrm{~nm}(\lambda 1)$ for $\mathrm{PA}$ and $219 \mathrm{~nm}(\lambda 2)$ for IB.

$$
\begin{aligned}
& \mathrm{C}_{\mathrm{x}}=\frac{\mathrm{A}_{2} \mathrm{ay}_{1}-\mathrm{A}_{1} \mathrm{ay}_{2}}{\mathrm{ax}_{2} \mathrm{ay}_{1}-\mathrm{ax}_{1} \mathrm{ay}_{2}} \\
& \mathrm{C}_{\mathrm{y}}=\frac{\mathrm{A}_{1} \mathrm{ax}_{2}-\mathrm{A}_{2} \mathrm{ax}_{1}}{\mathrm{ax}_{2} \mathrm{ay}_{1}-\mathrm{ax}_{1} \mathrm{ay}_{2}}
\end{aligned}
$$

Where, $\mathrm{C}_{\mathrm{x}}$ and $\mathrm{C}_{\mathrm{y}}=$ Concentration of PA and IB respectively in COAM $A_{1}$ and $A_{2}=$ Absorbance of PA at $\lambda_{1}$ and IB at $\lambda_{2}$ respectively $\mathrm{ax}_{1}$ and ay $=$ Absorptivity of PA and IB respectively at $\lambda_{1}$ $\mathrm{ax}_{2}$ and $\mathrm{ay}_{2}=$ Absorptivity of PA and IB respectively at $\lambda_{2}$

The saturation solubility of PA and IB at various $\mathrm{pH}$ viz. 1.2, 4.5, 6.8 and 7.2 was also determined using the same procedure. The experiments were performed in triplicate.

\section{2. 2. Micromeritics}

The particle size analysis of $\mathrm{PA}, \mathrm{IB}, \mathrm{BMP}, \mathrm{BMI}$ and COAM 1 was performed by ImageJ software using scanning electron microphotographs taken.

Flowability of PA, IB, BMP, BMI, PM and COAM 1 was assessed from angle of repose $(\theta)$. The value of $\theta$ was determined using fixed funnel free-standing cone method, performing measurement in triplicate, using the formula,

$$
\theta=\tan ^{-1}\left(\frac{\mathrm{H}}{\mathrm{R}}\right)
$$


Where, $\mathrm{H}(\mathrm{cm})$ is height between lower tip of funnel and base of sample, and $\mathrm{R}(\mathrm{cm})$ is the radius of the base of heap formed. ${ }^{31}$

The samples were also evaluated for Carr's compressibility index (CCI) and Hausner's ratio (HR) using the following formula,

$$
\begin{aligned}
& \mathrm{CCI}=\left(\frac{\mathrm{TD}-\mathrm{BD}}{\mathrm{TD}}\right) \times 100 \\
& \mathrm{HR}=\frac{\mathrm{TD}}{\mathrm{BD}}
\end{aligned}
$$

Where, TD and BD are tapped density and bulk density. ${ }^{32}$

\section{2. 3. X-ray Powder Diffraction (XRPD)}

XRPD patterns of PA, IB, BMP, BMI and COAM 1 were recorded at room temperature on X-ray diffractometer (Philips analytical XRPD, PW 3710, Holland) with $\mathrm{CuKa}$ radiation $(1.54 \AA)$, at $30 \mathrm{kV}, 10 \mathrm{~mA}$ and passing through a nickel filter. Samples were scanned between $10^{0}$ and $70^{\circ} 2 \theta$ with a step time of $16.5 \mathrm{sec}$ and step size of $0.02^{\circ}$.

\section{2. 4. Differential Scanning Calorimetry (DSC)}

Differential scanning calorimetry was used to assess thermal changes in PA, IB, BMP, BMI, and COAM 1. The study was carried out on model SDT Q600 V20.9 Build 20 (TA Instruments, USA). The DSC instrument was calibrated for temperature and heat flow using high-purity standards of indium. The samples $(3-5 \mathrm{mg})$ were heated $30^{\circ} \mathrm{C}$ to $300{ }^{\circ} \mathrm{C}$ at the rate of $10{ }^{\circ} \mathrm{C} / \mathrm{min}$. under dry nitrogen purge $(80 \mathrm{~mL} / \mathrm{min})$ in crimped and pin-holed aluminium pans. The melting points were determined using TA-Universal Analysis software (version 4.7A).

The percent crystallinity of all samples was calculated using an equation given by Rawlinson et al. ${ }^{33}$

$$
\text { Crystallinity }=\frac{\delta \mathrm{HmCOAM}}{\delta \mathrm{HmDrug} \times \mathrm{w}} \times 100
$$

Where, $\delta \mathrm{HmCOAM}$ is the melting enthalpy of the co-amorphous sample $\left(\mathrm{J} \mathrm{g}^{-1}\right), \delta \mathrm{HmDrug}$ is the melting enthalpy of drug $\left(\mathrm{J} \mathrm{g}^{-1}\right)$, and $\mathrm{W}$ is the weight fraction of drug in co-amorphous system $(\mathrm{W}=2 / 7=0.285$ for $\mathrm{IB}$ and $\mathrm{W}=$ $5 / 7=0.714$ for PA).

\section{2. 5. Attenuated Total Reflectance- Fourier Transform Infrared Spectroscopy (ATR-FTIR)}

ATR-FTIR spectra of PA, IB, BMI, BMP and COAM 1 were recorded using attenuated total reflectance infra red spectrophotometer (Bruker Alpha-T, India) to study the possible interactions between both drugs. About 3-4 mg of powdered sample was directly placed onto the ATR crystal and the spectrum was recorded over the wave number $400-4000 \mathrm{~cm}^{-1}$ on spectrophotometer.

\section{2. 6. Scanning Electron Microscopy (SEM)}

Scanning electron microphotographs of PA, IB, BMP, BMI, and COAM 1 were taken using SEM coupled EDAX (Model-JEOL-SEM 6360 A, Tescan, Brno-Czech Republic). An accelerating voltage of $12 \mathrm{kV}$ for PA and 18 $\mathrm{kV}$ for IB and COAM was used. Before taking microphotographs, the samples were coated with gold using Gold coating machine JEOL JFC- 1600.

\section{2. 7. In-vitro Dissolution Studies}

The in-vitro dissolution study for PA, IB, BMI, BMP and COAM 1 was carried out in USP type-II dissolution test apparatus (Electrolab Ltd., TDT 08L, Mumbai, India). Quantities equivalent to $500 \mathrm{mg}$ of PA and $200 \mathrm{mg}$ of IB were placed in the dissolution medium. The study was carried out for $2 \mathrm{~h}$ in $0.1 \mathrm{~N} \mathrm{HCl}$ and $2 \mathrm{~h}$ in phosphate buffer ( $\mathrm{pH}$ 7.2) with a rotation speed of $100 \mathrm{rpm}$ and dissolution media of $900 \mathrm{ml}$ at $37^{\circ} \mathrm{C}(\mathrm{n}=3)$. Five $\mathrm{ml}$ of samples were withdrawn and immediately replaced with same volume of fresh dissolution media. The filtered samples were analysed on UV-spectrophotometer (Jasco V-530, Japan) using simultaneous equation method.

\section{2. 8. Accelerated Stability Studies}

The COAM 1 samples were stored at $40{ }^{\circ} \mathrm{C} / 75 \% \mathrm{RH}$ for 3 months for accelerated stability studies. The samples were withdrawn after $0,30,60,90$ days and analyzed for angle of repose, XRPD, DSC and in-vitro dissolution.

\section{Result and Discussion}

\section{1. Preparation of COAM and Saturation Solubility Studies}

The saturation solubility of $\mathrm{PA}$ in distilled water, $\mathrm{pH}$ $1.2, \mathrm{pH} 4.5, \mathrm{pH} 6.8, \mathrm{pH} 7.2$, was found to be $17790.6 \pm 1.8$, $18616 \pm 2.4,18726.3 \pm 2.1,18022.2 \pm 1.9,18092.5 \pm 2.5 \mu \mathrm{g} /$ $\mathrm{mL}$ respectively. And, for $\mathrm{IB}$ in distilled water, $\mathrm{pH} 1.2, \mathrm{pH}$ 4.5, $\mathrm{pH} 6.8$, pH 7.2 was $78.3 \pm 1.1,47.1 \pm 1.2,65.2 \pm 1.6$, $128.9 \pm 0.9,181.1 \pm 1.0 \mu \mathrm{g} / \mathrm{mL}$ respectively. These values indicated that, $\mathrm{PA}$ solubility at various $\mathrm{pH}$ was invariably same, however, IB showed $\mathrm{pH}$-dependent solubility. The reason for $\mathrm{pH}$ dependent solubility is its weak acidic nature, which enhances solubility at higher $\mathrm{pH}$ values and reduces solubility at lower $\mathrm{pH} .34,35$ The water solubility of BMP and BMI was found to be $18050.4 \pm 1.6$ and $90.4 \pm$ $1.3 \mu \mathrm{g} / \mathrm{mL}$ respectively (solubility data for other $\mathrm{pH}$ values not shown). Which indicated that, although size reduction was noted (particle size data given under micromeritics) for BMP and BMI, significant increase in solubility was not demonstrated.

A combination of PA and IB was successfully ball milled in different clinical dose ratios to form COAM. The 
method involved mechanical activation of both the drugs using a ball mill and optimisation of milling time and speed after taking many trials in the view of conversion of a crystalline drug into amorphous counterpart and particle size reduction enhancing solubility and dissolution. ${ }^{36-39}$ In COAM, saturation solubility of IB in distilled water was altered after ball milling and was different for all dose combinations with PA, whereas, it was invariably same for PA, as depicted in Table 1. Maximum increase in aqueous solubility of IB was seen in $500 \mathrm{mg}$ : $200 \mathrm{mg}$ dose ratio (COAM 1 ), indicating role of PA and coamorphism towards solubility enhancement of IB, even if its solubility is $\mathrm{pH}$ dependent. Rise in aqueous saturation solubility of IB in COAM 1 from $78.3 \pm 1.1 \mu \mathrm{g} / \mathrm{ml}$ to $522.6 \pm 1.29 \mu \mathrm{g} / \mathrm{ml}$, confirmed 6.7 fold increase.

All the three clinical combinations showed increase in solubility of IB, but amongst them, COAM 1 showed maximum increase in solubility of IB. Thus, COAM 1 was selected for further characterization.

Table 1. Saturation solubility of PA and IB in COAM in various dose combinations

\begin{tabular}{lcr}
\hline $\begin{array}{l}\text { Dose combination } \\
(\mathbf{m g})(\mathbf{P A}+\mathbf{I B})\end{array}$ & $\begin{array}{c}\text { Saturation solubility in water }(\boldsymbol{\mu g} / \mathbf{m l}) \\
\text { PA }\end{array}$ & \multicolumn{1}{c}{$\mathbf{I B}$} \\
\hline $\mathbf{5 0 0}+\mathbf{2 0 0}($ COAM $\mathbf{1})$ & $17798.9 \pm 2.05$ & $522.6 \pm 1.29$ \\
$\mathbf{5 0 0}+\mathbf{4 0 0}($ COAM 2) & $17794.9 \pm 0.74$ & $387.7 \pm 3.24$ \\
$\mathbf{3 2 5}+\mathbf{4 0 0}($ COAM 3) & $17791.3 \pm 1.11$ & $83.9 \pm 1.93$ \\
\hline
\end{tabular}

\section{2. Micromeritics}

The average particle size of IB, BMI, PA, BMP and COAM 1 was found to be $191.07 \pm 12.69 \mu \mathrm{m}, 143.30 \pm 4.51$ $\mu \mathrm{m}, 17.06 \pm 2.11 \mu \mathrm{m}, 15.23 \pm 0.87 \mu \mathrm{m}$ and $4.75 \pm 0.37 \mu \mathrm{m}$ respectively. Which indicated the complimentary role of PA and IB towards size reduction in COAM during ball milling.

Studies have revealed poor flowability parameters for PA, IB, BMP, BMI and PM as given in Table 2. Both drugs possess poor flow properties, especially IB has very poor flow and processability problems due to its sticky nature. ${ }^{40-42}$ However, PA and IB in COAM 1 form demonstrated excellent flowability as indicated from CCI (19.2 \pm
$0.08)$ and HR $(1.25 \pm 0.04)$. Noteworthy, $\theta$ value, $30.3 \pm$ $0.51^{0}$ has clearly enunciated free flowing nature of COAM 1. Statistically, improvement in $\theta$ value of COAM 1 was significant $(\mathrm{P}<0.05)$, compared to rest all samples. Moreover, aforementioned flow parameters were also not satisfactory for BMP and BMI, although improved a bit with size reduction. Thus, remarkably improved flow property of IB in COAM is an indicator of reduced stickiness, uniform and size reduced particles, which divulges pivotal role of PA in improving flow, especially in COAM, unlike PM. In tabletting, addition of glidant has been recommended to improve flow properties by reducing strong interparticulate interactions. Herein, both $\mathrm{PA}$ and IB in COAM1 seem to perform the role of glidants. Newly generated fines of PA and IB during ball milling undergo strong adhesive interactions and deposits on energetic surfaces of PA crystals, thereby overcoming cohesive interactions. The deposit of PA-IB on paracetamol crystals may resemble miniscular form of solids designed, in which bigger but distorted PA crystals acts a carrier on which fine particulates of PA-IB deposit. ${ }^{43}$ Thus, such non-sticky particulates having improved processability, may increase its speed of production, reduces risk of stoppage and improves blend quality, filling procedures and end product quality. Conclusively, micromeritic properties have clearly unveiled, a new form of IB in COAM 1 which has resolved poor processability associated with its stickiness.

\section{3. X-ray Powder Diffraction (XRPD)}

$\mathrm{X}$-ray diffractograms of $\mathrm{PA}, \mathrm{IB}, \mathrm{BMP}, \mathrm{BMI}$ and COAM 1 have been depicted in Fig. 1. Crystalline peaks of PA have been noted at $2 \theta$ values $23.2,24.1,26.3$. Similarly, distinct and intense peaks of IB have been observed at 12.3, 16.7, 20.1, and 22.4. Powder X-ray diffractogram of individually ball milled drugs, BMP and BMI showed high intensity peaks revealing partial amorphism in PA and IB. This limited reduction in crystallinity of IB might be attributed to homodimer formation impeding crystallinity disruption. As anticipated, remarkable reduction in crystallinity of both PA and IB was divulged from diffractogram of COAM 1. The XRPD of COAM 1 shows some peaks of PA and two very low intensity peaks of IB which suggests almost complete amorphization of IB and outweighs role of $\mathrm{PA}$, along with milling force, in disruption

Table 2. Data for micromeritic properties of PA and IB (API, separately ball milled API, physical mixture, COAM 1)

\begin{tabular}{lccccc}
\hline Drug/s & $\begin{array}{c}\text { Bulk density } \\
(\mathbf{g} / \mathbf{m l})\end{array}$ & $\begin{array}{c}\text { Tapped density } \\
(\mathbf{g} / \mathbf{m l})\end{array}$ & $\begin{array}{c}\text { Carr's compressibility } \\
\text { index }(\mathbf{\%})\end{array}$ & $\begin{array}{c}\text { Hausner's } \\
\text { ratio }\end{array}$ & $\begin{array}{c}\text { Angle of } \\
\text { repose }(\boldsymbol{\theta})\end{array}$ \\
\hline PA & $0.216 \pm 0.01$ & $0.284 \pm 0.07$ & $23.90 \pm 0.14$ & $1.31 \pm 0.06$ & $39.8 \pm 0.80$ \\
IB & $0.231 \pm 0.09$ & $0.324 \pm 0.12$ & $28.70 \pm 0.22$ & $1.40 \pm 0.03$ & $43.4 \pm 1.21$ \\
BMP & $0.271 \pm 0.05$ & $0.355 \pm 0.03$ & $23.66 \pm 0.18$ & $1.31 \pm 0.10$ & $37.7 \pm 0.53$ \\
BMI & $0.246 \pm 0.01$ & $0.333 \pm 0.20$ & $26.12 \pm 0.13$ & $1.35 \pm 0.08$ & $40.9 \pm 0.80$ \\
PM & $0.321 \pm 0.05$ & $0.431 \pm 0.06$ & $25.52 \pm 0.31$ & $1.34 \pm 0.13$ & $40.0 \pm 0.67$ \\
COAM 1 & $0.353 \pm 0.02$ & $0.437 \pm 0.04$ & $19.20 \pm 0.08$ & $1.25 \pm 0.04$ & $30.3 \pm 0.51$ \\
\hline
\end{tabular}




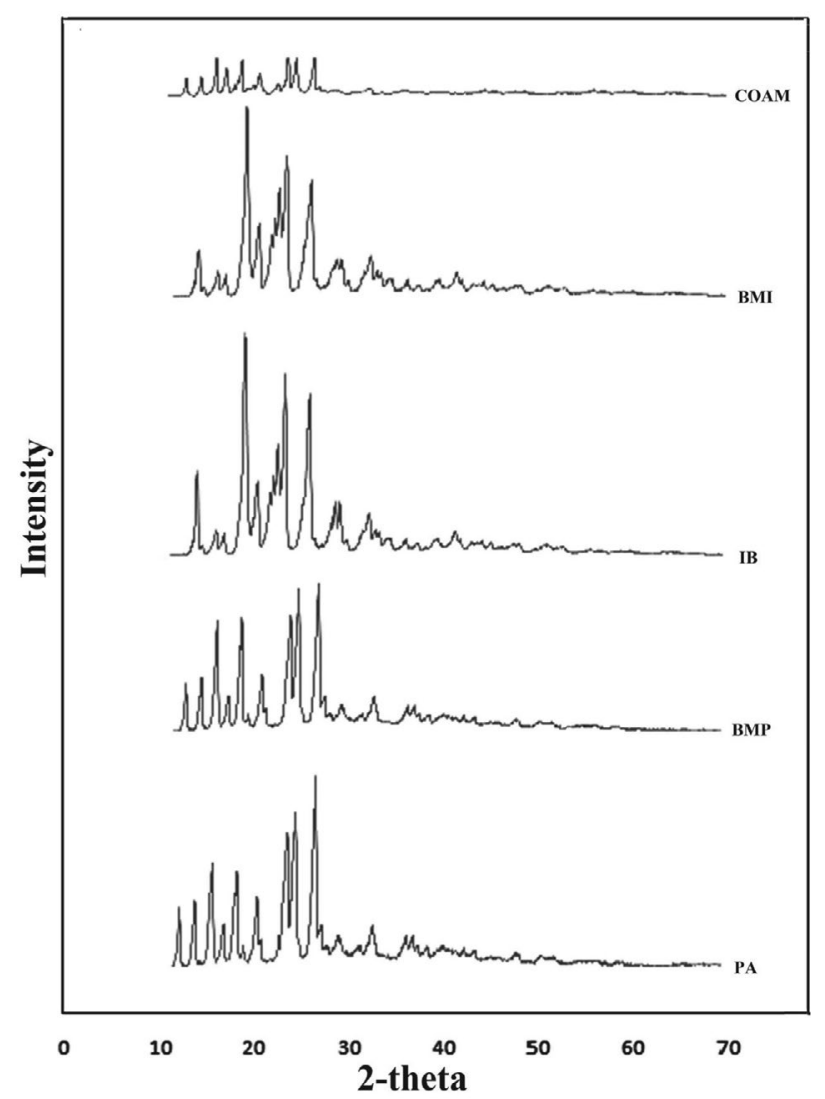

Figure 1. XRPD diffractogram of plain PA and IB, ball milled PA and IB, and COAM 1 samples

of IB geometry. The conversion of IB in co-amorphous form was responsible for increase in its aqueous solubility, although it has $\mathrm{pH}$ dependent solubility. ${ }^{44,45}$

\section{4. Differential Scanning Calorimetry (DSC)}

The DSC thermogram (Fig. 2) of PA and IB showed sharp endothermic transitions at $170.05{ }^{\circ} \mathrm{C}$ (Fig. 2a) and $77.9^{\circ} \mathrm{C}$ (Fig. 2c) respectively, corresponding to their melting points. A second endothermic peak seen in thermogram of IB at $223{ }^{\circ} \mathrm{C}$, was corresponding to its boiling point. ${ }^{46}$ The figure depicts slight changes in the crystallinity of BMP (Fig. 2b) and BMI (Fig. 2d), whereas, in COAM 1 , significant transformation of both crystalline PA and IB to amorphous form. Interestingly, shift in melting point of PA from $170.05^{\circ} \mathrm{C}$ (in PA) to $159.6^{\circ} \mathrm{C}$ (in COAM 1) has been noted (Fig. 2e) and boiling point of IB at $223^{\circ} \mathrm{C}$ was also not observed in DSC of COAM 1, indicating strong solid state interactions between PA and IB, and partial dissolution of PA in molten IB. ${ }^{28}$ The details of $\%$ crystallinity of both the drugs have been given in Table 3 . The \% crystallinity of PA and IB in COAM 1 sample was found to be $44.37 \%$ and $9.63 \%$ respectively. Whereas, $\%$ crystallinity of BMP was $77.44 \%$, and $91.42 \%$ for BMI, which was quiet high, compared to COAM 1.

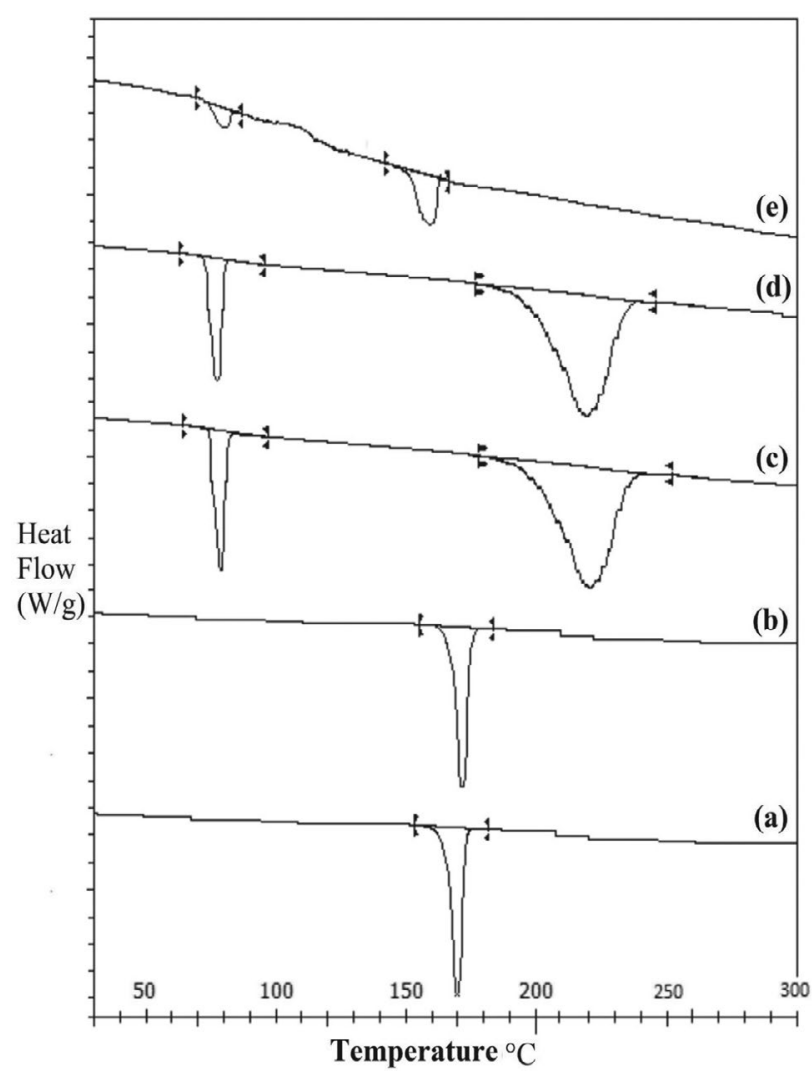

Figure 2. DSC thermogram of (a) PA, (b) BMP, (c) IB, (d) BMI and (e) COAM 1

Table 3. Enthalpy and \% crystallinity of COAM 1 after a) 0 days, b) 30 days, c) 60 days and d) 90 days (accelerated stability samples)

\begin{tabular}{lcccr}
\hline COAM 1 & \multicolumn{2}{c}{ Enthalpy $(\mathrm{J} / \mathrm{g})$} & \multicolumn{2}{c}{ \% Crystallinity } \\
& PA & IB & PA & IB \\
\hline 0 days & 79.87 & 12.40 & 44.37 & 9.63 \\
30 days & 83.94 & 12.90 & 46.63 & 10.01 \\
60 days & 86.45 & 13.80 & 48.02 & 10.71 \\
90 days & 88.54 & 14.20 & 49.18 & 11.03 \\
\hline
\end{tabular}

\section{5. Attenuated Total Reflectance- Fourier Transform Infrared Spectroscopy (ATR-FTIR)}

Till date, ATR-FTIR has been considered as a workhorse for studying drug-drug interactions. The ATRFTIR spectra of COAM 1 (Fig. 3c) reveals shift in phenolic $\mathrm{C}=\mathrm{O}$ stretch of $\mathrm{PA}\left(1372.1 \mathrm{~cm}^{-1}\right)$ to higher wave number $1396.84 \mathrm{~cm}^{-1}$. Similarly, N-H stretch of amide in PA at $3162.69 \mathrm{~cm}^{-1}$ was also shifted to higher wave number. For IB, $\mathrm{C}=\mathrm{O}$ stretch of carboxylic acid $\left(1714.41 \mathrm{~cm}^{-1}\right)$ was shifted to lower wave number at $1647.77 \mathrm{~cm}^{-1}$. And, $\mathrm{O}-\mathrm{H}$ stretch of carboxylic acid of IB at $2953.45 \mathrm{~cm}^{-1}$ was shifted to higher wave number $\left(2980.20 \mathrm{~cm}^{-1}\right)$. The ATRFTIR spectra (Fig. 3) shows shift in wave numbers sug- 


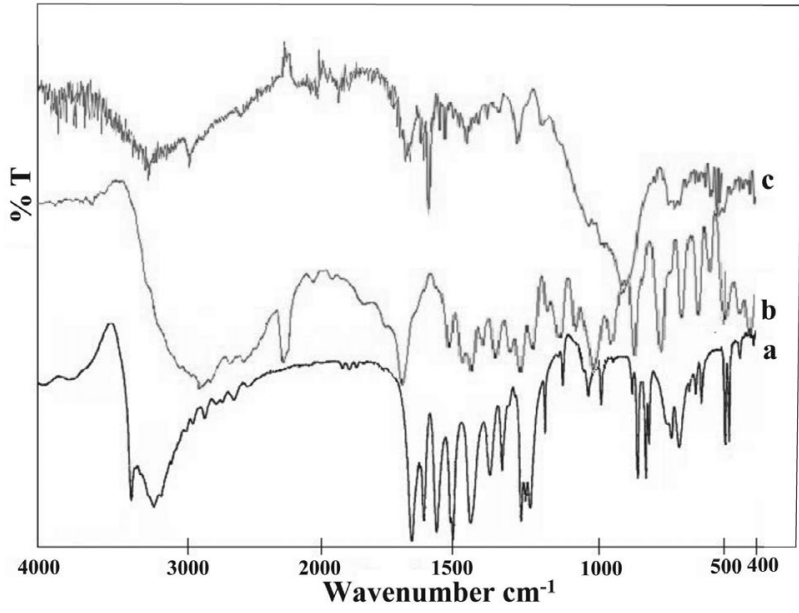

Figure 3. ATR-FTIR spectra of (a) PA, (b) IB, and (c) COAM 1

gesting strong hydrogen bonding interactions between PA and IB.

As mentioned previously, increased solubility and dissolution of IB in COAM 1 system was due to molecular
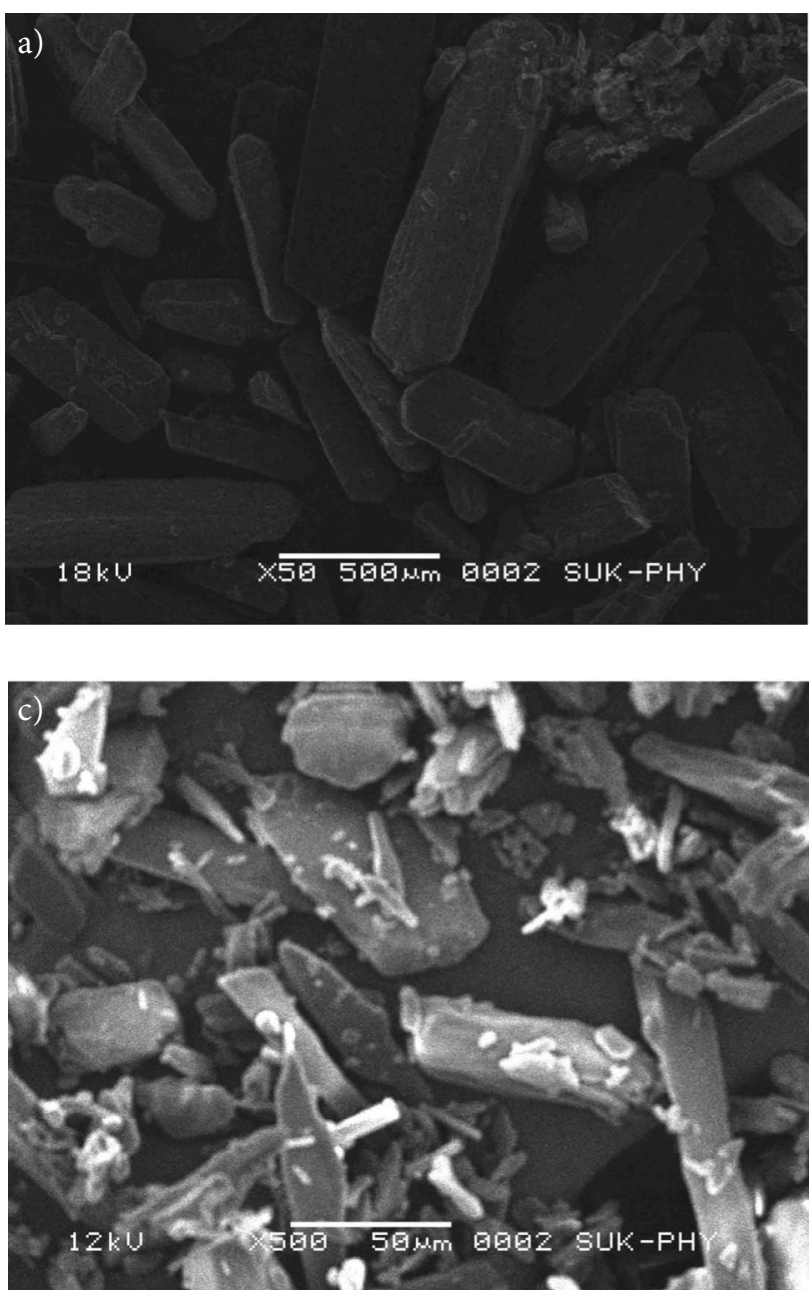

interactions between PA and IB. ${ }^{21,22}$ Even, adsorption of PA-IB fine particulates on PA, might have generated a miniscular form as discussed earlier. Such strong adhesive molecular interactions might have lead to band shifts in the IR spectra. ${ }^{47,48}$ These shifts are also observed when a crystalline drug is converted into its amorphous form. ${ }^{48}$ Here, molecular interaction between PA and IB were confirmed due to shift of phenolic $\mathrm{C}=\mathrm{O}$ stretch, $\mathrm{N}-\mathrm{H}$ stretch (amide) of $\mathrm{PA}$ and $\mathrm{C}=\mathrm{O}$ stretch, $\mathrm{O}-\mathrm{H}$ stretch (carboxylic acid) of IB.

\section{6. Scanning Electron Microscopy (SEM)}

The microphotographs taken using SEM showed long, slender, needle shaped crystals of IB (Fig. 4a and 4b), and Fig. 4c shows irregular shaped crystals of PA. Distorted crystal morphology and extensively reduced grain size along with congregated PA and IB clearly indicated partial transformation of crystal form of PA to its amorphous state, and almost complete crystallinity loss for IB in COAM 1 (Fig. 4d).
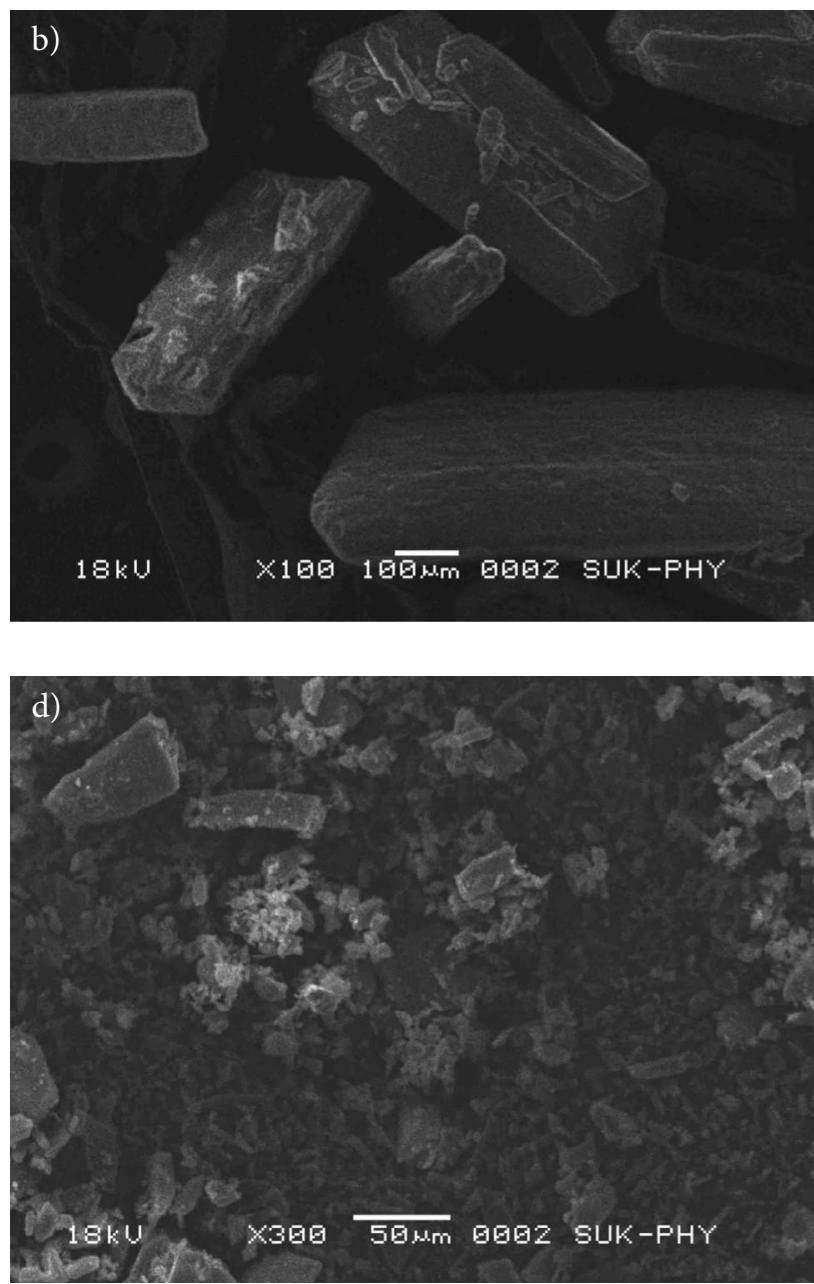

Figure 4. Scanning electron microphotograph of (a) IB [50x], (b) IB [100 x], (c) PA [500x] and (d) COAM 1 [300x] 


\section{7. In-vitro Dissolution Studies}

In-vitro dissolution profile of PA, IB, BMP, BMI, and COAM 1 in $0.1 \mathrm{~N} \mathrm{HCl}$ and phosphate buffer $\mathrm{pH} 7.2$ is depicted in Fig. 5. It is known that particle size reduction enhances dissolution of drugs ${ }^{36-40}$ but, is not a sole reason for improved dissolution. This can be explained by the dissolution profile of BMP and BMI, in which the dissolution of individually milled drug was not improved. It has also been reported in previous studies that both ball milling at room temperature and cryogenic ball milling of IB only slightly reduced its crystallinity. ${ }^{49}$ For plain PA to dissolve in phosphate buffer pH 7.2, it took 40 min (Fig. 5c; data not shown in table), and in co-amorphous form showed $80 \%$ dissolution in $0.1 \mathrm{~N} \mathrm{HCl}$, in 20 min (Fig. 5a). There was a insignificant difference $(\mathrm{P}<0.05)$ found in the dissolution of PA, BMP, and PA in its co-amorphous form in both dissolution media.

On the contrary, IB in co-amorphous form showed improved dissolution in both the dissolution media. In 0.1 $\mathrm{N} \mathrm{HCl}$, dissolution of IB, BMI, and IB in PM was poor $(10.26 \pm 0.41 \%$ in $2 \mathrm{~h}$ for plain IB) which can be seen in Fig. 5b, whereas, remarkable improvement was noted in dissolution of IB in COAM $1(14.55 \pm 0.45 \%$ in $2 \mathrm{~h})$, which was 1.5 times more. Interestingly, in phosphate buffer $\mathrm{pH}$ 7.2, COAM 1 showed $99.80 \pm 0.58 \%$ dissolution of IB in $20 \mathrm{~min}$ (Table 4$)$, which was significantly high $(\mathrm{P}<0.05)$ compared to plain IB ( $63 \pm 0.27 \%)$. Moreover, at 5 and 10 minute time points, the dissolution of IB in COAM was double to that of plain IB, highlighting likely rapid onset of action. For plain IB to be completely dissolved it took 90 $\min (98.3 \pm 0.69 \%)$, and similar were observations for dissolution of IB from BMI and PM (Fig. 5d).

\section{8. Stability Studies}

Angle of repose of COAM 1 demonstrated an insignificant change for stability samples (data not shown). Diffractometric analysis demonstrated slight increase in intensity of the peaks of COAM 1, as seen in Fig. 6. Similarly, slight increase in enthalpy and \% crystallinity was observed in DSC thermogram of COAM 1. Percent crystallinity of IB after three months was raised to $11.03 \%$ from initial $9.63 \%$ and of PA was increased to $49.18 \%$ from initial $44.37 \%$. Slight increase in crystallinity of IB has been reflected in its In vitro dissolution profiles. With slight increase in crystallinity and reduction in amorphism, \% IB dissolved has been slightly reduced (Table 4).

Accelerated stability studies suggested that the COAM 1 samples were stable up to 3 months. Neither the flowability, XRPD, DSC results nor the in-vitro dissolution studies showed significant change thus confirming stability of the product. Inhibition of propensity of amorphous material to devitrify was evident from these findings. Eventually, PA not only assisted in disruption of IB crystallinity, but, also stabilised its amorphous form at molecular level.

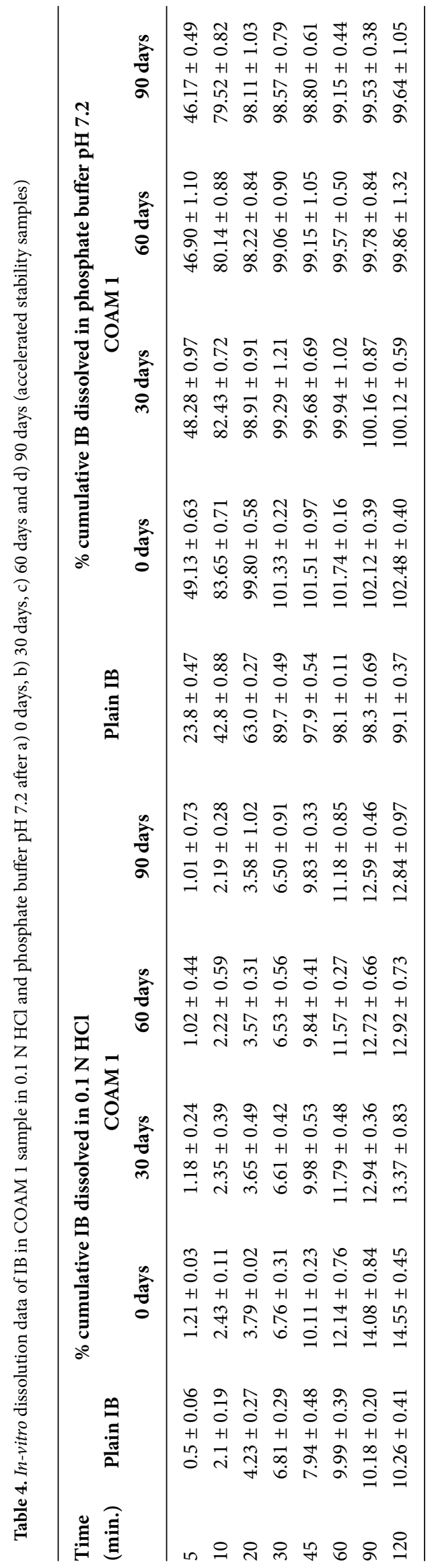



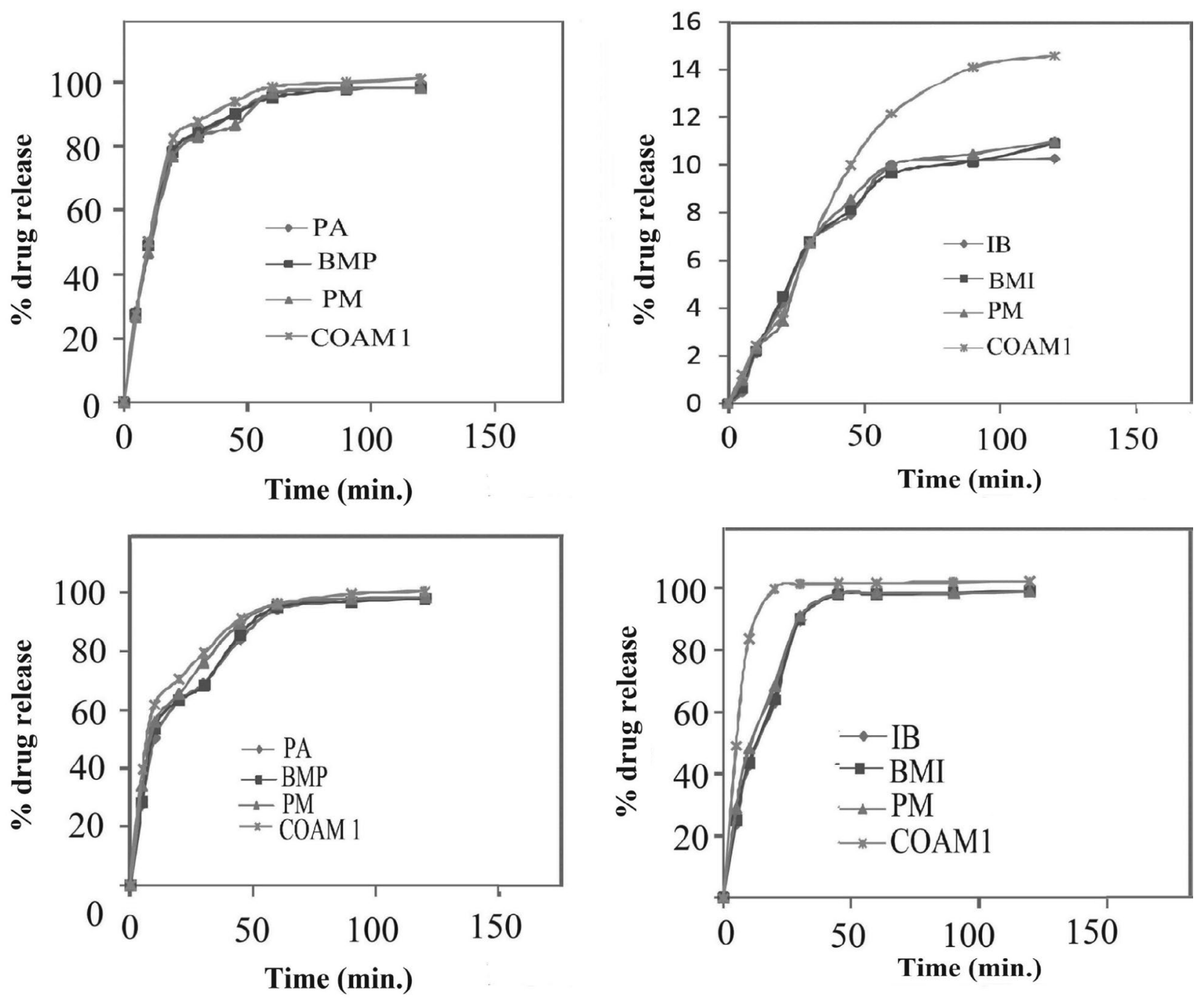

Figure 5. In-vitro dissolution profile of (a) PA in $0.1 \mathrm{~N} \mathrm{HCl}$, (b) IB in $0.1 \mathrm{~N} \mathrm{HCl}$, (c) PA in phosphate buffer (pH 7.2) and (d) IB in phosphate buffer (pH 7.2)

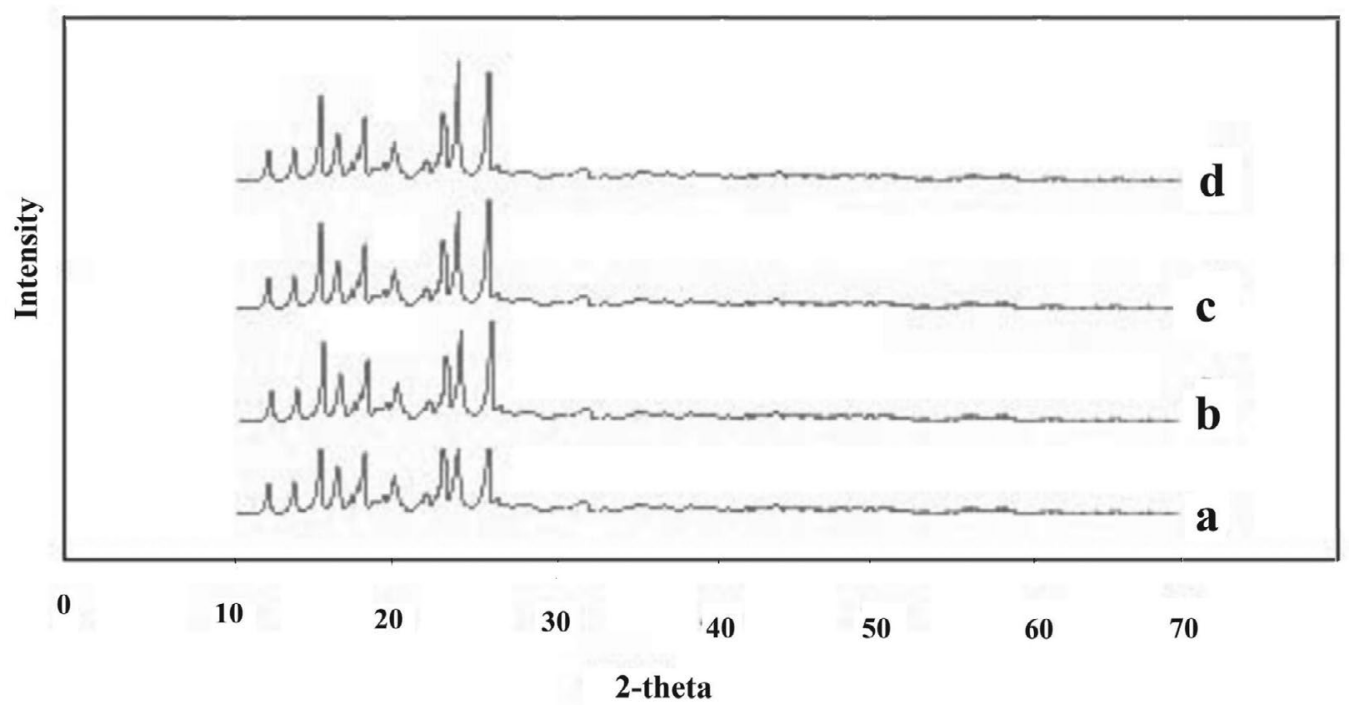

Figure 6. XRPD of COAM 1 after a) 0 days, b) 30 days, c) 60 days and d) 90 days at accelerated stability conditions 


\section{Conclusion}

Paracetamol-Ibuprofen co-amorphous system was successfully generated by ball milling technique. Flow properties of IB were satisfactorily improved in co-amorphous form, thus overcoming its problem of stickiness, processability and homodimer formation during sizing down. Diffractometric studies have revealed amorphism/ reduced crystallinity of IB and its subsequent stabilisation by PA. Amorphization and subsequent adsorption of IB on PA can speculate generation of a particulate system similar to miniscular dosage form. As a consequence, the COAM 1 form of IB demonstrated approximately seven fold solubility enhancement and threefold increase in dissolution of IB. Since, individually ball milled drugs did not show any significant increase in solubility and dissolution, the role of coamorphism for IB and essential role of PA has been unveiled. The presence of PA with IB in COAM could outweigh over the role of particle size of both in solubility and dissolution enhancements. Hence, work has demonstrated generation of COAM form of PA and IB in clinical dose ratio $500 \mathrm{mg}: 200 \mathrm{mg}$, which may overcome poor processability, solubility and dissolution, and bioavailability constraints of IB. The method being simple, green, cost effective, and novel for PA-IB combination, holds great industrial potential.

\section{Acknowledgements}

Authors are thankful to AICTE, New Delhi, India for Providing Junior Research Fellowship to Mayuri Bhandari.

\section{Declaration of Interest section}

The authors report no declarations of interest.

\section{References}

1. H. Potthast, J. B. Dressman, H. E. Junginger, K. K. Midha, H. Oeser, V. P. Shah, J. Pharm. Sci. 2005, 94, 2121-2131.

DOI:10.1002/jps.20444

2. E. Dudognon, F. Danède, M. Descamps, T. Correia, Pharm. Res. 2008, 25, 2853-2858.

DOI:10.1007/s11095-008-9655-7

3. Md. A. A. Masum, F. Sharmin, S. M. A. Islam, Md. S. Reza, Dhaka Univ. J. Pharm. Sci. 2012, 11, 1-6.

4. M. Newa, K. H. Bhandari, D. X. Lee, J. H. Sung, J. A. Kim, B. K. Yoo, J. S. Woo, Drug Dev. Ind. Pharm. 2008, 34, 1013-21. DOI:10.1080/03639040701744095

5. M. M. Gupta, M. G. Patel, N. S. Patel, M. Kedawat, Int. J. Pharm. Pharm. Sci. 2011, 3, 204-206.

6. S. Mallick, S. K. Pradhan, M. Chandran, M. Acharya, T. Digdarsini, R. Mohapatra, Results Pharma Sci. 2011, 1, 1-10.

DOI:10.1016/j.rinphs.2011.05.003

7. M. Dixit, P. K. Kulkarni, S. Panner, Int. Res. J. Pharm. 2011, 2, 250-256.

8. K. A. Bodek, Acta Pol. Pharm. 2002 59, 105-108.
9. A. Ousset, P. Chavez, J. Meeus, F. Robin, M. A. Schubert, P. S. and K. Dodou, Pharmaceutics.2018, 10, pii: E29.

DOI:10.3390/pharmaceutics10010029.

10. A. T. Serajuddin, J. Pharm. Sci. 1999, 88, 1058-1066. DOI:10.1021/js9804031

11. J. Vijay, J. T. Sahadevan, R. M. Gilhotra, Chron. Young Sci. 2012, 3, 95-105. DOI:10.4103/2229-5186.98668

12. G. Z. Papageorgiou, S. Papadimitriou, E. Karavas, E. Georgarakis, A. Docoslis, D. Bikiaris, Curr. Drug. Deliv. 2009, 6, 101-12. DOI:10.2174/156720109787048230

13. D. Kayrak, U. Akman, O. Hortacsu, The J. Supercrit. Fluids. 2003, 26, 17-31. DOI:10.1016/S0896-8446(02)00248-6

'4. A. Nokhodchi, A. Homayouni, R. Araya, W. Kaialy, W. Obeidat, K. Asare-Addo, RSC Adv. 2015, 5, 46119-46131. DOI:10.1039/C5RA06183K

15. T. E. Sintra, K. Shimizu, S. P. M. Ventura, S. Shimizu, J. N. Canongia Lopes and J. A. P. Coutinho, Phys. Chem. Chem. Phys. 2018, 3, 2094-2103.

16. Katerina Stoyanova, Zahari Vinarov, Slavka Tcholakova, Improving ibuprofen solubility by surfactant-facilitated self-assembly into mixed micelles, J Drug Deliv Sci Technol. 2016, 36, 208-215 DOI:10.1016/j.jddst.2016.10.011

17. A. Hillerström, J. Stam, M. Andersson, Green Chem. 2009, 11, 662-667. DOI:10.1039/B821281C.

18. C. Gerardin, J. Reboul, M. Bonne, B. Lebeau, Chem. Soc. Rev. 2013, 42, 4217-4255.

19. P. Zhang, J. Forsgren, M. Stromme, Int. J. Pharm. 2014, 472, 185-191. DOI:10.1016/j.ijpharm.2014.06.025

20. M. Acharya, S. Mishra, R. N. Sahoo, S. Mallick, Acta Chim. Slov. 2017, 64, 45-54. DOI:10.17344/acsi.2016.2772

21. N. Chieng, J. Aaltonen, D. Saville, T. Rades, Eur. J. Pharm. Biopharm. 2009, 71, 47-54. DOI:10.1016/j.ejpb.2008.06.022

22. M. Alles $ø$, N. Chieng, S. Rehder, J. Rantanen, T. Rades, J. Aaltonen, J. Controlled Release 2009, 136, 45-53.

DOI:10.1016/j.jconrel.2009.01.027

23. T. Masuda, Y. Yoshihashi, E. Yonemochi, K. Fujii, H. Uekusa, K. Terada, Int. J. Pharm. 2012, 422, 160-169.

DOI:10.1016/j.ijpharm.2011.10.046

24. K. Grzybowska, M. Paluch, P. Wlodarczyk, A. Grzybowski, K. Kaminski, L. Hawelek, Mol. Pharmaceutics. 2012, 9, 894-904. DOI:10.1021/mp200436q

25. E. Kaminska, K. Adrjanowicz, M. Tarnacka, K. Kolodziejczyk, M. Dulski, E. Mapesa, Mol. Pharmaceutics. 2014, 11, 2935-2947. DOI:10.1021/mp500286b

26. S. Yamamura, H. Gotoh, Y. Sakamoto, Y. Momose, Int. J. Pharm. 2002, 241, 213-221.

DOI:10.1016/S0378-5173(02)00195-3

27. K. Löbmann, R. Laitinen, H. Grohganz, K. C. Gordon, C. Strachan, T. Rades, Mol. Pharmaceutics. 2011, 8, 1919-1928. DOI:10.1021/mp2002973

28. K. Löbmann, C. Strachan, H. Grohganz, T. Rades, O. Korhonen, R. Laitinen, Eur. J. Pharm. Biopharm. 2012, 81, 159169. DOI:10.1016/j.ejpb.2012.02.004

29. S. Wairkar, R. Gaud, AAPS PharmSciTech. 2016, 17, 673-681. DOI:10.1208/s12249-015-0371-4

30. H. Ueda, W. Wu, K. Loebmann, H. Grohganz, A. Müllertz, 
and T. Rades, Mol. Pharm. 2018, 15, 2036-2044

DOI:10.1021/acs.molpharmaceut.8b00174

31. D. Train, J. Pharm. Pharmacol. 1958, 10, 127 T-135 T.

32. R. L. Carr, J. Chem. Eng. 1965, 72, 163-168.

33. C. F. Rawlinson, A. C. Williams, P. Timmins, I. Grimsey, Int. J. Pharm. 2007, 336, 42-48.

DOI:10.1016/j.ijpharm.2006.11.029

34. I. E. Shohin, J. I. Kulinich, G. F. Vasilenko, G. V. Ramenskaya, Indian J. Pharm. Sci. 2011, 73, 443-446.

35. A. Anil Kumar, T.E. Gopala Krishna Murthy, A. Prameela Rani, World j. pharm. pharm. sci. 2014, 3, 311-324.

36. Z H Loh, A. K. Samanta, P. W. S. Heng, Asian J. Pharm. Sci. 2015, 10, 255-274. DOI:10.1016/j.ajps.2014.12.006

37. P. Khadka, J. Ro, H. Kim, I. Kim, J. T. Kim, Asian J. Pharm. Sci. 2014, 9, 304-316. DOI:10.1016/j.ajps.2014.05.005

38. J. Sun, F. Wang, Y. Sui, Z. She, W. Zhai, C. Wang. Y. Deng, Int. J. Nanomed. 2012, 7, 5733-5744. DOI:10.2147/IJN.S34365

39. J. Jinno, N. Kamada, M. Miyake, K. Yamada, T. Mukai, M. Odomi, J. Controlled Release 2006, 111, 56-64.

DOI:10.1016/j.jconrel.2005.11.013

40. N. Rasenack, B. W. Muller, Int. J. Pharm. 2002, 245, 9-24.

DOI:10.1016/S0378-5173(02)00294-6
41. A. Nada, B. W. Mueller, S. M. Al-Saidan, Pharm. Technol. 2005, 29, 1-8

42. H. Ehlers, H. Räikkönen, O. Antikainen, J. Heinämäki, J. Yliruusi, Int. J. Pharm. 2009, 368, 165-170.

DOI:10.1016/j.ijpharm.2008.10.013

43. N. Jadhav, A. Pawar, A. Paradkar, AAPS Pharm Sci Tech 2007, 8, Article 59, E1-E7.

44. S. B. Murdande, M. J. Pikal, R. M. Shanker, R. H. Bogner. Pharm. Dev. Technol. 2011, 16, 187-200.

DOI:10.3109/10837451003774377

45. M. A. Czarnecki, Y. Morisawa, Y. Futami, Y. Ozaki, Chem. Rev. 2015, 115, 9707-9744. DOI:10.1021/cr500013u

46. S. Ramukutty, E. Ramachandran, J. Cryst. Process Technol. 2014, 4, 71-78. DOI:10.4236/jcpt.2014.42010

47. S. Shen, P. S. Chow, F. Chen, R. B. H. Tan, Chem. Pharm. Bull. 2007, 55, 985-991. DOI:10.1248/cpb.55.985

48. A. Heinz, C. J. Strachan, K. C. Gordon, T. Rades, J. Pharm. Pharmacol. 2009, 61, 971-988. DOI: 10.1211/jpp.61.08.0001

49. S. M. Lee, H. J. Park, S. S. Kim, T. H. Choi, E. Kim, K. H. Na, H. K. Cho, K. Y. Rhee, Materials Science Forum. 2005, 475479, 2403-2406.

DOI:10.4028/www.scientific.net/MSF.475-479.2403.

\section{Povzetek}

Material (oznaka COAM) sestavljen iz amorfega paracetamola (PA) in ibuprofena (IB) smo pripravili $\mathrm{z}$ mletjem $\mathrm{v}$ krogličnem mlinu. Namen raziskave je bil pripraviti material $\mathrm{z}$ višjo topnostjo in boljšim raztapljanjem ibuprofena. Tako pripravljeno amorfno mešanico paracetamola in ibuprofena smo karakterizirali z rentgensko praškovno difrakcijo (XRDP), diferenčno dinamično kalorimetrijo (DSC) infrardečo spektroskopijo (ATR-FTIR), vrstično elektronsko mikroskopijo (SEM) in opravili in vitro študije raztapljanja in stabilnosti. Največje povečanje (6,7-kratno) topnosti ibuprofena v vodi smo opazili v vzorcu, ki smo ga pripravili v odmerkih 500 (PA) : 200 (IB) mg (oznaka COAM 1). Topnost se je povečala iz 78,3 $\pm 1,1 \mu \mathrm{g} / \mathrm{ml}$ na $522,6 \pm 1,29 \mu \mathrm{g} / \mathrm{ml}$. V vzorcu (COAM 1) smo določili 99,80 $\pm 0,58 \%$ raztapljanje ibuprofena $\mathrm{v}$ dvajsetih minutah $\mathrm{v}$ fosfatnem pufru, kar kaže na znatno povečanje $\mathrm{v}$ primerjavi s samim ibuprofenom. Tako je bila za razliko od paracetamola ugotovljena bistveno izboljšana topnost in hitrost raztapljanja ibuprofena. $\mathrm{V}$ vzorcu (COAM 1) je bila tudi izjemno izboljšana pretočnost v primerjavi s čistim ibuprofenom. Le-ta je najverjetneje posledica močnih adhezivnih interakcij v sistemu PA-IB. Rezultati XRPD in DSC so potrdili amorfno obliko ibuprofena. Rezultati ATR-FTIR spektroskopije kažejo na prisotnost interakcij preko vodikovih vezi med obema učinkovinama. Pospešeni testi stabilnosti, rezultati meritev pretočnosti, XRPD, DSC in testi in vitro raztapljanja so potrdili uspešno stabilizacijo ibuprofena s paracetamolom. 